\title{
0 jogo de cena da escritura no Grande sertão: veredas, de Guimarães Rosa: leituras derridianas
}

\author{
Paulo Cesar S. de Oliveira (UFRJ)* \\ http://orcid.org/000-0002-3710-4722
}

\section{Resumo:}

Este artigo estuda a estrutura narrativa do romance Grande sertão: veredas, de João Guimarães Rosa, a partir da concepção de escritura (écriture) pensada por Jacques Derrida, bem como das considerações do filósofo sobre a instituição literária. Nossa hipótese de trabalho se concentra na ideia de que no Grande sertão: veredas o fenômeno da escritura é uma questão central. Partiremos de uma passagem da obra, que trata de uma carta enviada pela personagem Nhorinhá e que somente chega a seu destinatário, Riobaldo, quando já e tarde demais, para discutir a questão do evento e do acontecimento, segundo uma pergunta de Riobaldo sobre os efeitos da carta, caso ela tivesse chegado a tempo. A isso, chamaremos de "metáfora escritural", que regula um pensamento sobre a escrita, em geral, e sobre a escritura literária, em particular. Com isso, Rosa nos adianta questões como traço, evento, devir, além de problematizar o "como se" da literatura, elementos organizadores de um saber próprio do literário. Finalmente, propomos a abordagem destas provocações de Guimarães Rosa em seu único romance como alguns dos modos de entrada na obra.

Palavras-chave: Jacques Derrida; Desconstrução; Grande sertão: veredas; Teoria.

\section{Abstract:}

\section{The writing game in the Grande sertão: veredas, by Guimarães Rosa: derridian readings}

This article studies the narrative structure of the novel Grande sertão: veredas, by João Guimarães Rosa, based on the concept of writing (écriture) thought by Jacques Derrida, as well as the philosopher's considerations about the literary institution. Our working hypothesis focuses on the idea that in the Grande sertão: veredas the phenomenon of writing is a central

* Professor Adjunto de Teoria Literária da Universidade do Estado do Rio de Janeiro/FFP e membro permanente do Programa de Pós-Graduação em Letras e Linguística da UERJ/FFP (PPLIN). Bolsista de Produtividade em Pesquisa pelo CNPq (PQ) e Bolsista do Programa de Incentivo à Produção Técnica e Artística (PROCIÊNCIA) da FAPERJ. E-mail: paulo.centrorio@uol.com.br. 
issue. We will start from a passage of the work, which deals with a letter sent by the character Nhorinhá and that only reaches its recipient, Riobaldo, when it is too late, to discuss the question of the event and the experience, according to a question posed by Riobaldo about the effects of the letter, in case it had arrived in time. We will call it the "scriptural metaphor" which regulates an understanding about the writing, in general, and about literary writing, in particular. With this, Rosa discusses issues such as trait, event, becoming, besides, problematizing the "as if" of literature, by organizing elements of the literary knowledge. Finally, we propose to approach these provocations led by Guimarães Rosa in his only novel as some of the possibilities of entering the novel.

Keywords: Jacques Derrida; Deconstruction; Grande sertão: veredas; Theory.

Uma poética literária constrói suas trilhas, atalhos, veredas no direito ilimitado de fazer todas as perguntas, provocando os centros reguladores. No romance Grande sertão: veredas, de João Guimarães Rosa (1986), o direito à pergunta aponta para um jogo de cena e para uma potência reflexiva que nos interessam analisar: no jogo de cena, encontramos um diálogo no qual a personagem central, o iletrado Riobaldo, se dirige a um interlocutor letrado, de quem não sabemos o nome e que em nenhum momento terá "direito" à resposta ou mesmo à fala; já a potência reflexiva se manifesta também a partir do jogo de cena, no momento em que provoca os leitores atentos a questionar, no trânsito narrativo da obra, o "como se" de sua estruturação poética, especialmente quando seus receptores chegam a uma passagem do enredo relativa a uma carta. Essas considerações merecerão explicações adicionais que situarão nossos interlocutores no problema proposto neste artigo.

Os leitores do Grande sertão: veredas (doravante, citado pelas abreviações Gsv, seguidas da página correspondente à edição do romance utilizada) sabem que se trata de uma narrativa, no plano da enunciação, controlada pela personagem central, Riobaldo, também ele o narrador. Riobaldo se situa em um presente da leitura atualizado pelos leitores atentos que, no desenrolar da trama, seguirão a personagem em suas jornadas, situando-se no plano das ações, propriamente ditas, dado pelos enunciados, acompanhando a mesmo tempo as emaranhadas questões apresentadas pelo Riobaldo sujeito da enunciação.

A história que Riobaldo conta ao interlocutor pode ser resumida na paixão proibida pelo amigo Diadorim, que desestabiliza seu mundo supostamente ordenado e que, já quase ao final do romance, os leitores descobrem ser, na verdade, Maria Deodorina da Fé, antes transfigurada na persona de Diadorim. A suspensão do segredo acerca da identidade de Diadorim ocorre no momento de sua morte, quando a realização da paixão interditada já não será mais passível de se realizar. A revelação do segredo será, portanto, a morte do próprio segredo, que permanece, enquanto fenômeno, em sua inviolabilidade. No Gsv, a história do amor jamais consumado entre Riobaldo e seu companheiro nas lidas e lutas dos tempos de jagunçagem se transforma em uma espécie de "como se" do romance e da literatura, em geral. Dito de outro modo, Guimarães Rosa cria uma narrativa que não se descola, no plano do enunciado, da ação e da represen- 
tação da paisagem e da reflexão existencial acerca do caminho - elementos que povoam as jornadas interna e externa de Riobaldo e Diadorim junto a seus companheiros jagunços na paisagem sertaneja mineira. Já no plano da enunciação, revela-se uma série de imagens e passagens que podem levar o leitor atento a traçar hipóteses de leitura produtivas acerca de uma poética em ação. Em nosso caso, falaremos de uma "poética de trânsito" ou de "trânsitos narrativos", elementos que estruturam um modo de ser da escrita no Gsv.

Neste artigo, nos valeremos de uma imagem que recorta o romance e que, articulada com uma série de leituras de textos de Jacques Derrida, revelam novas relações entre a escrita literária de Rosa, a problemática dos sujeitos e de suas identidades e o mundo circundante no qual interagem: a carta de Nhorinhá; a carta enviada e jamais recebida ou lida; carta direcionada a um destinatário certo, mas que se transformou em texto de endereço incerto; a carta extraviada, que circula, mas não chega ou só chega quando é tarde demais; a carta coo questão reguladora de um saber acerca da obra, de sua constituição e de suas provocações ao leitor. Assim como a escritura, compreendida como algo que se lança para o futuro, em um devir incessante, suspensa no tempo se não houver alguém que a receba, a carta é representada no romance do Rosa como uma espécie de metáfora da própria escrita, pois só pode ser sancionada por quem a recebe e interrompida em sua jornada no espaço-tempo somente pela morte, que é a interrupção de tudo o que se pode narrar. E que carta é essa? Pensemos, agora, no contexto narrativo do Gsv.

Riobaldo conhecera a jovem Nhorinhá em uma breve passagem pela região da Aroeirinha e ambos se prometeram em casamento.
0 fato ocorre antes de Riobaldo reencontrar o então menino Reinaldo, sujeito emblemático de sua infância e que se transformara no belo, impetuoso e perturbador Diadorim, seu futuro companheiro de cangaço. Nhorinhá escreve uma carta a Riobaldo, que neste meio tempo perambulava pelo sertão, em suas andanças de jagunço. Nela, a jovem reafirmava seu afeto e o desejo de ser sua parceira de vida. Quando finalmente recebe a carta, Riobaldo se encontra, como ele mesmo diz a seu interlocutor, nos tempos de "range rede", na velhice, e gozando da paz de sua fazenda. Riobaldo está casado, Diadorim morto e a fase da jagunçagem se encerrou. Ao ler a carta que lhe chega inesperadamente, e que até então continuava perdida, vagando pelo sertão, Riobaldo reflete sobre a possibilidade de felicidade que já não poderá se concretizar; sobre o tempo perdido que não voltará e sobre as possibilidades de sua vida caso a carta chegasse a tempo, antes que a jornada de jagunço atravessasse dramaticamente sua vida.

É neste momento da velhice que Riobaldo poderá compreender com uma clareza relativa que "os fatos passados obedecem à gente; os em vir também" (Gsv, p. 321). Riobaldo entende que algo que não sabia em seu passado, no presente ele apenas não compreende. Ele percebe que só podemos domar no presente os fatos passados pelo trabalho da memória, da imaginação e da interpretação: a primeira é fluida, pouco confiável; a segunda, se assemelha à poética artística, ao trabalho dos poetas; e a terceira pode ser comparada ao trabalho da crítica, mas não se restringe a ela. Ao chegar quando já é (muito) tarde, a carta de Nhorinhá revelará a Riobaldo que seu passado somente poderá ser recuperado em migalhas, pelas ruínas do que foi, seja através da memória falha seja pela imaginação, que procura 
dar sentido àquilo que para ele será sempre a ponta de um mistério:

Quando recebi a carta, vi que estava gostando dela, de grande amor em lavaredas; mas gostando de todo tempo, até daquele tempo pequeno em que com ela estive, na Aroeirinha, e conheci, concernente amor. Nhorinhá, gosto bom ficando em minha boca. De lá para lá, oito anos se baldavam. Nem estavam. Senhor subentende o que isso é? A verdade que, em minha memória, mesmo ela tinha aumentado de ser mais linda. De certo, agora não gostasse mais de mim, quem sabe até tivesse morrido... Eu sei que isto que estou dizendo é dificultoso, muito entrançado (ROSA, 1986, p. 93).

É essa memória duvidosa, incerta, que pontua o diálogo/monólogo de Riobaldo, mas para o leitor ela é também motivo para reflexões mais amplas, que culminam no próprio relato, no desvelamento da experiência manifestada pela forma de contar, representada pela escritura, que implica a representação de uma voz fingida - a de Riobaldo narrador - que se dirige a um suposto interlocutor da cidade, cuja fala jamais será ouvida pelos leitores do romance, posto que é apenas pressuposta através do que nos conta o narrador, isto é: a palavra do sujeito letrado é eludida no jogo de cena da escritura.

Com isso, a escrita do Gsv provoca alguns centros reguladores da instituição literária que colocam em segundo plano a fala do iletrado, destituído.

Se Rosa, o autor-empírico, ainda é o senhor do relato, no plano da enunciação ele cria um sujeito subalterno representado como o "senhor da fala" que discute justamente este poder dado a determinado sujeito, quer o chamemos de autor, quer o compreendamos como sujeito hegemônico, com direito à voz. 0 letrado, sujeito da cidade, encontra-se, no relato, subordinado, sob o do- mínio daquele que, em condições normais, seria subjugado pelo poder de fala concedido aos que dominam a letra, a escrita, em suma. É um jogo textual que, se por um lado, revela concessão à voz do subalterno, por outro, ainda mantém a voz do concedente como uma instância de autoridade, posto que ele assina o texto, cuja contra-assinatura - sua validação, reconhecimento e avaliação - será dada pelos leitores potenciais.

Portanto, a questão da carta é uma espécie de fio condutor que nos ajuda a pensar as infinitas potencialidades da literatura como instituição e como movimento de trânsitos textuais e críticos incessantes, em resumo: lugar de onde se parte e de onde é possível formular todas as perguntas. A poética do Gsv desarticula a regulamentação, a autoridade do autor, ao mesmo tempo em que a decompõe e analisa: no plano da autoridade do escritor, o romance mantém a estrutura do poder a ele concedido, que é o de firmar sua palavra pelo nome, por uma assinatura; já no plano da escrita em si, da representação, desconstrói o centro regulador, visto que se parte de um ponto do círculo no qual há uma sanção, embora fingida, da autoridade hegemônica do autor em prol do "como se" da literatura que, nos limites cerrados da escritura do romance, concede poderes ao sujeito subalterno.

Essas estratégias nos levam a pensar na reflexão de Jacques Derrida (1991b, p. 103) quando, ao analisar o Fedro, de Platão, nos dirá:

A escritura e a fala são, pois, dois tipos de rastros, dois valores do rastro; um, a escritura, é rastro perdido, semente não viável, tudo o que no esperma se gasta sem reserva, força extraviada fora do campo da vida, incapaz de engendrar, de se repor e regenerar a si mesma. Ao contrário, a fala viva nos faz frutificar o capital, ela não desvia a potência seminal para um gozo sem paternidade. 
Gozo sem paternidade, adiamento do gozo erótico e da consumação do desejo, excesso e contenção, economia e transbordamento, fala verborrágica e silêncio, a escritura - que é sem pai - se contrapõe à fala, misto de voz e paternidade, subordinando-a à violência da desconstrução, trama que a nosso ver já havia sido encenada na poética do Gsv.

A notória questão "por onde começar?" talvez seja inadequada para o romance de Rosa. Mas é imperativo a toda lógica do discurso que um começo visível se apresente, embora a narrativa do Gsv não nos facilite na realização dessa tarefa. A palavra-labirinto pontua a linha narrativa adotada por Rosa e coloca para o historiador das ideias e para o crítico literário problemas de difícil solução: precisamos de um começo visível (!), um ponto de entrada por onde possamos penetrar nos bosques ficcionais de Rosa (acharemos o fio da meada?), mas neles não há origem, começos visíveis, há apenas segredo, e este permanece para sempre oculto, indisponível, pois é a condição de ser do segredo e também estratégia discursiva de Rosa. Resta-nos, portanto, o texto, isto é, aquilo que se apresenta como aspecto físico da obra: a organização das páginas, os grifos, signos em profusão e em caótica apresentação, tudo que, no romance roseano, estrutura a obra em sua poética - uma narrativa sem divisões, composta por uma voz indicada e reconhecida por meio de um travessão (que é um traço estético-formal essencial para se entender a estratégia de Rosa, posto que a fala de Riobaldo se dá em um átimo, uma só respiração, sem fim ou fechos).

Compreendemos que a escritura é sempre e já rejeição de uma suposta unidade e coerência discursivas. Sabemos, como dito, ao iniciar a leitura do Gsv, que Riobaldo é o sujeito que controla o romance e que sua fala é uma representação reconhecida através de um dado da escrita: o travessão. $\mathrm{E}$ esse traço é o que representa a ausência da fala concreta dada pela voz. Dizemos que Riobaldo "fala", mas poderíamos dizer: "narra", "comanda" seu discurso. E se ele fala, a quem se dirige, quem é seu narratário, esse suposto interlocutor que ouve atentamente a ininterrupta e aparentemente caótica descrição dos fatos e pensamentos, cujos contornos retóricos revelam um sem-número de ideias disseminadas, "causos" que o sujeito-narrador irá pacientemente desfiar:

Eu sei que isto que estou dizendo é dificultoso, muito entrançado. Mas o senhor vai avante. Invejo é a instrução que o senhor tem. Eu queria decifrar as coisas que são importantes. E estou contando não é uma vida de sertanejo, seja se for jagunço, mas a matéria vertente. Queria entender do medo e da coragem, e da gã que empurra a gente para fazer tantos atos, dar corpo ao suceder. 0 que induz a gente para más ações estranhas, é que a gente está pertinho do que é nosso, por direito e não sabe, não sabe, não sabe! (ROSA, 1986, p. 93).

Por ora, essas palavras serão suficientes para localizarmos nosso narrador em sua relação com o narratário. Se a "matéria vertente" é "dificultosa" e "entrançada", não menos importante é o desejo de Riobaldo de "decifrar as coisas", penetrar seus "códigos secretos" que, para ele, são a chave da compreensão do mundo. Notemos que o que Riobaldo chama de "matéria vertente" não possui homologia aparente com a "vida de sertanejo" ou de jagunço, visto que privilegia a reflexão à mera representação do real ou a descrição pormenorizada das ações e aventuras. Lembremos ainda que, a toda ação descrita no romance sucede uma reação do pensamento. No entanto, se o caráter mimético desta narrativa ficcional se faz 
onipresente no panorama geral da obra, ainda que constantemente questionado e desconstruído, isso nos leva a crer que há modos de leitura bem mais produtivos se partirmos de um referencial marcante: o espaço romanesco representado no Grande sertão se materializa entre a transcrição da paisagem e a escritura do caminho. Riobaldo diz: “Assim, é como conto. Antes conto as coisas que formaram passado para mim com mais pertença" (ROSA, 1986, p. 93). Portanto, não é simplesmente um estudo da ambientação ou das ações o que o leitor terá nas mãos, já que a obra não é somente uma narrativa concentrada no espaço, embora o espaço seja predominante; e nem há simplesmente a superposição da visão historiográfica sobre o artifício da representação ficcional de um passado nos moldes da tradição literária. 0 que nos chega às mãos e provoca a leitura é o dado fundamental que caracteriza a compreensão histórica, conforme pensou Walter Benjamin (1985): o acontecimento na forma como poderia ter ocorrido em um momento de perigo, pois viver é muito perigoso - esta frase é repetida incessantemente no Gsv. Assim, o narratário requisitado teria a função de compreender para organizar, ir adiante, recontar: "Mas o senhor é homem sobrevindo, sensato, fiel como papel, o senhor me ouve, pensa e repensa, e rediz, então me ajuda" (ROSA, 1986, p. 93).

O narratário, o sujeito letrado, será apresentado e sua imagem construída, passo a passo, como um tipo de "tradutor" de uma realidade caótica que Riobaldo tenta organizar através da fala, porém, sem muito êxito, do ponto de vista da lógica da clareza, embora preze pela sensatez e fidelidade aos fatos, que ele repensa e reconstrói, fazendo aparecer diante dos olhos do leitor uma realidade que experimentou enquanto a rememora e problematiza. Estamos já, aqui, rondando as questões que mais tarde invocaremos como papel fundamental do leitor desta obra, como aquele que coloca, ao lado da assinatura de um autor, no caso, Guimarães Rosa, sua contra-assinatura, elemento assim pensado por Derrida (1991a, p. 35):

Por definição, uma assinatura escrita implica a não presença atual ou empírica do signatário. Mas, dir-se-ia, marca também e retém o seu ter-sido presente num agora passado, que permanecerá um agora futuro, logo, um agora em geral, na forma transcendental da permanência. Essa permanência geral está de algum modo inscrita, presa na pontualidade presente, sempre evidente e sempre singular, da forma de assinatura. Nisso consiste a originalidade enigmática de todas as rubricas. Para que a vinculação à fonte se produza, é preciso pois que seja guardada a singularidade absoluta de um acontecimento de assinatura e de uma forma de assinatura: a reprodutibilidade pura de um evento puro.

Derrida se pergunta sobre a possibilidade de algo deste tipo: "a singularidade absoluta de um evento de assinatura" (DERRIDA, 1991a, p. 36) produzir-se alguma vez, em algum momento, ou seja: haveria assinaturas? A resposta que ele dá é sim, "todos os dias", posto que "os efeitos da assinatura são a coisa mais corrente no mundo", com as ressalvas de que as condições de possibilidade desses efeitos são, simultaneamente e, paradoxalmente, "a condição de sua impossibilidade, da impossibilidade de sua pureza rigorosa" (DERRIDA, 1991a, p. 36). Por isso, uma assinatura tem como condição para sua existência uma forma repetível, iterável, imitável, uma "mesmidade" que altera a identidade e a singularidade da assinatura.

Voltando ao interlocutor no Gsv, sua função é homóloga ao trabalho do intérprete, isto é, do leitor, mudo diante do texto, porém, com a tarefa de contra-assinar, o que 
é feito através da atividade leitora. Se o romance nos chega sob a forma de uma obra caótica, de uma narração disseminada, "não-organizada", ou melhor, conformada à lógica do sujeito que narra, que pode se contrapor à lógica daquele tipo de leitor que espera uma certa estruturação mais clara e objetiva, então, a questão de quem escreve do autor, repitamos - retorna com força, assim como avulta o problema da leitura e do leitor, necessariamente evocado/convocado a completar o texto, a assiná-lo:

Mas, o senhor sério tenciona devassar a raso este mar de territórios, para sortimento de conferir o que existe? Tem seus motivos. Agora - digo por mim - o senhor vem, veio tarde. Tempos foram, os costumes demudaram. Quase que de legítimo leal, pouco sobra, nem não sobra mais nada (ROSA, 1986, p. 24, grifos nossos).

Por isso, a verdade maior do texto do Gsv resulta na descostura de certos nós, o que provoca a destituição dos regimes de poder e de verdade que por acaso ainda nos assombrem: "O senhor vem, veio tarde". Essa é a condição do narratário, mas também revela a natureza de todo leitor, que só pode existir pressuposto pelo texto ou em função de uma economia textual e de uma linguagem literária que se constroem através da dissolução das oposições metafísicas tradicionalmente aceitas como representações de uma verdade. 0 senhor vem. 0 texto vem. Ele nos chega quando já é tarde. Ele é rastro de rastros e o questionamento sobre sua verdade, sendo um pressuposto do próprio texto, está enredado no movimento da escrita que dialoga com o "para-fora-desi" dado pelo texto, que permanece sempre em estado de clausura (preso na página, no suporte digital, no livro etc.): mire e veja, atente e desatente, encubra, descubra, recubra, tente completar essa "estória sem final"
(ROSA, 1986, p. 297).

0 narrador se endereça ao narratário diversas vezes, já dissemos, e algumas consequências deste ato também divisamos anteriormente. Esses endereços visam a dar forma, direção, conselho ao narratário para que este reescreva e reinterprete o percurso narrado. Trata-se, portanto, de indicações "transparentes" que servem como auxílio ao narratário, tanto quanto para o leitor dito modelo. Porém, a intermitente questão colocada pelo narrador é a da própria desconfiança em relação ao que ele próprio narra: "Agora que mais idoso me vejo, e quanto mais remoto aquilo reside, a lembrança demuda de valor - se transforma, se compõe, em uma espécie de decorrido formoso"; ou ainda: "... penso como um rio tanto anda: que as árvores das beiradas mal nem vejo... Quem me entende?"; e, na mesma passagem: "Então onde está a verdadeira lâmpada de Deus, a lisa e real verdade?" (ROSA, 1986, p. 321).

Se entre as indicações transparentes que descobrimos no texto e a intenção de dar visibilidade, clareza, ao fato narrado existe um abismo (uma das imagens construída pela prosa do Gsv), não caberia ao leitor decidir sobre o ponto final da interpretação, isto é: determinar quais seriam os postulados mais válidos para a leitura da obra, em detrimento de outros? Em resposta a uma pergunta de Patrick Mahoney, Derrida (1995b, p. 108) disse: "Não estou certo de que um apelo ou um endereçamento seja endereçado a quem ele é endereçado. Há, então, elementos ao acaso, arbitrários, ativos, em todo tipo de mensagem, em todo tipo de carta, em toda correspondência, se preferir" (Nossa tradução). ${ }^{1}$ São esses elementos -

1 No original: I cannot be assured that an appeal or an address is addressed to whom it is addressed. There are, then, aleatory or chance elements at 
rastros, diferenças, traços, sombras, espectros, indecidíveis etc. - que perturbam as seguras indicações transparentes que abalam a crença em um idioma absoluto regulando qualquer obra.

A narrativa do Gsv tem seus princípios, seus reclames: "a gente principia as coisas, no não saber por que, e desde aí perde o poder de continuação - porque a vida é mutirão de todos, por todos remexida e temperada" (ROSA, 1986, p. 430). Por isso, a interpretação conclama a alteridade, mutirão e vinda de outro(s): "Se vendo minha alma estou vendendo também os outros" (ROSA, 1986, p. 291), diz Riobaldo, o pactário. E quem é seu leitor? Igualmente pactário de um acordo com o texto, no texto, abandonado à virulência da diferença e da disseminação, como nos mostra Derrida.

Diz Riobaldo ao narratário: "Aí, narro. 0 senhor me releve e suponha" (ROSA, 1986, p. 431); "O senhor me organiza? Saiba: essas coisas, eu pouco pensei, no lazer de um momento" (ROSA, 1986, p. 341); "O senhor, mire e veja, o senhor: a verdade instantânea dum fato, a gente vai departir, e ninguém crê"( ROSA, 1986, p. 408); “Com que entendimento eu entendia, com que olhos era que eu olhava? Eu conto. O senhor vá ouvindo. Outras artes vieram depois" (ROSA, 1986, p. 137); “Amável o senhor me ouviu, minha ideia confirmou: que o Diabo não existe. Pois não?" (ROSA, 1986, p. 568). São questões que não (se) fecham. Não fecham questão. Fechar questão sobre algo é não negociar, não aceitar ou permitir a vinda do outro. E esse outro que vem? Quando vem? Quando chega a carta àquele a quem ela se destina? 0 Grande sertão é uma estrutura poética de adiamento, "inde-cisão", nostalgia, luto, impossibilidade, segredo

work in every kind of message, every type of letter, all mail, if you will. dispêndio - o gozo adiado de uma paixão que só chega quando já nada se pode fazer ou o gozo nostálgico que poderia ter sido caso a carta chegasse a tempo. Não estaremos então nos arredores da escritura, rondando o texto como "a" diferença, o diferido, conforme pensou Derrida?

A questão da carta é um componente estrutural que regula a narrativa. Explica o porquê de já não se poder "contar seguido, alinhavado" e de a narrativa suceder desgovernada, sendo então aquilo que chega quando intervêm a memória e a lembrança. Explica, ainda, por que há tanta desconfiança em relação às questões do mundo e do ser, ou seja, entre mundo e ser. Mais ainda, esclarece porque Riobaldo não consegue penetrar no coração do segredo, permanecendo sempre no nível da pré-compreensão que antecede o conhecimento do fenômeno sem, no entanto, atingi-lo pela ação: "de-cisão" que ele não toma, que adia, transferindo ao narratário a pergunta que Riobaldo não (se) responde, mas cujos efeitos ele quer compreender no ocaso da vida, em tempos de range rede.

Desta forma, enquanto o Riobaldo sujeito do enunciado vive o tempo de aguardar e o tempo da ação, enquanto experimenta o mundo em que circula e no qual interage, 0 Riobaldo dos tempos de range rede, como sujeito da enunciação, vive o tempo de rememorar. Entre os dois momentos, seria no tempo do enunciado que o leitor esperava por parte de Riobaldo a tomada de uma decisão. A decisão que ele não toma, e, assim como a carta, não chega ao presente, é uma espécie de adiamento no tempo, ela é a energia economizada - talvez indevidamente - para a eventualidade de uma futura abertura da questão: quem sou, que paixão é essa que me desorganiza? Quando chega o tempo de vivê-la? 
Chegar quando já é tarde, descoberta no momento em que a revelação não apazigua, não resolve. Assim, o fenômeno da carta, da vida que não foi, retorna como uma das formas de repetição do problema da escritura, que reverbera na narrativa: iterabilidade. ${ }^{2}$ Por exemplo, quando Riobaldo descobre que seu padrinho é uma das pontas do mistério de sua origem, de seu nome - e o Gsv é uma narrativa exemplar das políticas do nome próprio (Riobaldo, Tatarana, Professor; o "menino" Reinaldo, mais tarde, Diadorim e, finalmente, Deodorina) - já é tarde demais para desprezo ou amor. Somente pela nostalgia dos tempos idos, pela rememoração, Riobaldo atualizará as questões que, nos tempos da juventude, o conclamavam, sem sucesso, à reflexão. Ao lembrar do pai/padrinho, Riobaldo dirá: “[...] quando velho, ele penou remorso por mim; eu, velho, a curtir arrependimento por ele. Acho que nós dois éramos mesmo pertencentes" (ROSA, 1986, p. 107). Riobaldo nos lança em meio a uma "poética do quase", homóloga às próprias questões que a escritura - retornemos ao modelo da carta - vai demandar.

A problemática da escritura relacionase à própria definição do fenômeno como o aparente/inaparente; alétheia, aquilo que se esconde e manifesta. Mas o que traz a questão da carta enquanto contribuição para uma poética de autor que distende a noção da escritura? Diremos, provisoriamente, que ela fala de uma confusão nos estatutos logocêntricos através dos quais a vida se organiza,

2 Iterabilidade é o momento repetido, repetível, em que o enunciado é submetido ao escrutínio do outro (alteridade), e configura a propriedade de todo signo, de ser repetido na ausência de um referente e de seu significado ou mesmo de uma intenção determinada. A iteração implica, ao mesmo tempo, identidade e diferença de discursos, aquilo que arrasta nossos corpos para o discurso e nos caracteriza como sujeitos atravessados pelos discursos. segundo uma lógica determinada. 0 mundo do logos prevê o acaso como uma manifestação da própria dinâmica racional, cujo acontecimento será percebido erroneamente nas instâncias de um centro regulador. Daí que temporalidade e espacialidade devem ser compreendidos como partes de uma estrutura que organiza as contradições aparentes do texto em prol de uma síntese apaziguadora.

Derrida (1991c) procura estabelecer, pelo conceito de espaçamento, uma diferença dentro dessa suposta segurança espacial/ temporal - tomando de empréstimo aos escritos de Stéphane Mallarmé - mostrando como os elementos produzidos nos intervalos da cadeia espacial/temporal compõem o "tornar-se ausente", "tornar-se inconsciente" do sujeito. A época da escritura trata desses espaçamentos. Entre a escritura da carta e o conhecimento de seu conteúdo pelo destinatário (que é Riobaldo, no caso, mas poderíamos falar de um destinatário qualquer), uma sucessão de rastros nos dá conta de uma história que jamais poderá ser reconstruída, quer seja pelo emitente, pelo destinatário ou pelo leitor, que, no máximo, pode transitar pelas passagens abertas no texto:

Mas a carta gastou uns oito anos para me chegar; quando eu recebi, eu já estava casado. Carta que se zanzou, para um lado longe e para o outro, nesses sertões, nesses gerais, por tantos bons préstimos, em tantas algibeiras e capangas. Ela tinha botado por fora só: "Riobaldo que está com Medeiro Vaz". E veio trazida por tropeiros e viajores, recruzou tudo. Quase não podia mais se ler, de tão suja dobrada, se rasgando. Mesmo tinham enrolado noutro papel, em canudo, com linha preta de carretel. Uns não sabiam mais de quem tinham recebido aquilo. Último, que me veio com ela, quase por engano de acaso, era um homem que, por meio da doença do toque, ia levando seu gado de volta dos gerais para a caatinga, logo que chuva chovida (ROSA, 1986, p. 92-3). 
O movimento da carta repete e reafirma o movimento da escritura. Ele reinscreve a noção socrática, depois consolidada por Platão, da escritura como significante secundário, uma espécie de significante de significante - chega quando já é tarde, ao contrário da fala, que é o presente no presente, presentificação da ação, da vontade - cujo percurso funda as oposições temáticas que constituem a origem e o percurso histórico da filosofia. A fala seria a "expressão" do logos como origem da verdade, enquanto a escritura se afirmaria como mero instrumento de fixação (no espaço exterior) da fala, cuja "essência" é interna, nos diz o pensamento metafísico, socrático-platônico.

A relação entre fala e escritura foi sempre pensada pelas respectivas oposições entre dentro e fora, inteligível e sensível, essência e aparência, verdadeiro/falso, que constituem a cadeia metafísica no percurso histórico da ideia. Mas, observemos que, no contexto da carta enviada por Nhorinhá, os conceitos de tempo e espaço são desafiados por um jogo metafórico que perturba a cadeia discursiva. Chamaremos de "metáfora escritural" esse movimento textual que demarca as múltiplas possibilidades da escritura na sua diferenciação em relação à fala no Gsv. 0 espaçamento, isto é, a exterioridade do espaço, o fazer-se espaço no tempo indica que o traço escritural (a carta de Nhorinhá) não pode se resumir no dizer-se presente. Ele é o próprio movimento no espaço e no tempo, abrindo-se como um "fora" dentro do movimento da temporalização. A carta percorre o sertão sem jamais dizer "presente" e, portanto, ela não é presente-asi, posto que depende da chegada (ao) do outro. Assim, é a própria instituição da "presença-a-si" que o movimento da carta como "metáfora escritural" desregula. Ela chega quando não é mais possível traduzir verda- de como presença, nem fazer da presença a verdade que a voz advoga como princípio de identidade. Ao contrário, a escritura vive de uma promessa que o logos não pode assegurar. Como artifício, veneno (uma das pontas do phármakon, que Derrida, em $A$ farmácia de Platão (1991b) esmiúça sobremaneira), ela não prevê remetente ou destinatário; ela pode inclusive não chegar ao seu destino e este percurso é uma espécie de fazerse "fora" no "dentro", que é o tempo; pode mesmo perder-se ou apagar-se, chegar a outro (s) destinatário (s) possível (eis); enfim, provoca a segurança do ser presente no discurso, supostamente dada pela phoné.

O sujeito da escritura é sempre alguém previsto no horizonte do texto, daí que a escritura, embora sempre manifesta no momento de atualização pela leitura, não se resume ao presente. Como diz Silviano Santiago (1976, p. 34), “o espaçamento marca o tornar-se ausente e o tornar-se inconsciente do sujeito". Nhorinhá já não é um ente real e presentificável (e se ela em pessoa chegasse para declarar seu amor a Riobaldo?) dado pela segurança da voz; já Riobaldo é um ser tocado pela impossibilidade de restaurar no presente uma possibilidade que a carta não pode mais concretizar, visto que chega tarde demais. Ela somente atualiza aquele passado perdido, que pode ser rememorado no presente, presentificando aquele "algo" que não pode mais ter lugar. 0 apresentar-se das coisas já é uma impossibilidade-em-si: tudo o que Riobaldo vai narrar repete a metáfora escritural contida na imagem da carta. Riobaldo age quando não pode mais declarar presente. Assim, a estrutura de enganos, de acasos, indecidíveis, rastros e traços que caracterizam a metáfora escritural regula o universo da narrativa e é a marca do trágico em Riobaldo. Ainda assim, precisaríamos confirmar nossa hipótese e os exemplos que 
já trouxemos ao debate - a identidade de Diadorim, a carta de Nhorinhá, a reflexão sobre a vida que poderia ter sido etc. - nos dão conta, aparentemente, disso.

São nessas passagens propiciadas pela obra, nesses trânsitos textuais, que buscamos um caminho reflexivo que toca o pensamento de Derrida, acerca da escritura e que, a nosso ver, Guimarães Rosa ficcionalizou com rara felicidade. A lei da composição: estar sempre destituída de centro. 0 que origina uma condenação da escrita por Platão, segundo Derrida (1991b) - ela é veneno - é, hoje, saída para certos impasses. Não que isso signifique o idealismo da busca da verdade, mas sim a defesa da complexidade face à redução empobrecedora que assola o pensamento em certas épocas históricas. E encontramos aqui um momento-chave, inaugurando uma questão na qual repousa a tese central deste texto: a compreensão do fenômeno da escritura - cuja análise preparatória estivemos a esboçar - confunde-se com a natureza do fenômeno literário, atada à crítica da metafísica. Isto é, na esteira da crise do pensamento filosófico, a reflexão que busca compreender o literário - e, por conseguinte, a escritura - só poderá estabelecer-se na discussão dos impasses que hoje norteiam a chamada contemporaneidade.

Sendo assim, o que se espera de um questionamento sobre o literário é menos a velha crítica impressionista e mais o elogio de uma forma de reflexão do ser e do mundo. E esse elogio, para início de conversa, se estabelece na diferença. Falemos, pois, deste princípio, incansavelmente defendido por Derrida: a différance, que estabelece o jogo conceitual que elimina o nome de "origem" que cada palavra posta à mesa pela língua metafísica que carrega. Différance é "o movimento pelo qual a língua, ou qualquer código, qualquer esquema de reenvios em geral se constitui 'historicamente' como tecido de diferenças" (DERRIDA, 1991c, p. 43), significando que todo signo remete obrigatoriamente a outro(s) que lhe(s) é (são) diferente(s). Esse sistema abala a crença na origem, estabelecendo uma relação de não-conformidade com o esquema presente, passado, futuro - estruturas temporais metafisicamente comprometidas -, desconstruindo a lógica do sistema ao descentralizá-lo, estabelecendo uma nova "marca" temporal:

A diferença é o que faz com que o movimento da significação não seja possível a não ser que cada elemento dito "presente", que aparece sobre a cena da presença, se relacione com outra coisa que não ele mesmo, guardando em si a marca do elemento passado e deixando-se já moldar pela marca da sua relação com o elemento futuro, relacionandose o rastro menos com aquilo a que se chama presente do que aquilo a que se chama passado, e constituindo aquilo a que chamamos presente por intermédio dessa relação mesma com o que não é ele próprio: absolutamente não ele próprio, ou seja, nem mesmo um passado ou um futuro como presentes modificados (DERRIDA, 1991c, p. 45).

Essa nova "marca" temporal, se a utilizarmos para o entendimento da escrita literária - compreendida por Derrida como um produto diferido, uma instituição, mas, ainda assim um artefato da escritura - irá mostrar que a historicidade da obra não se confunde com seu passado, mas incide na "impossibilidade que ela experimenta de alguma vez ser no 'presente", de ser resumida em qualquer simultaneidade ou instantaneidade absolutas" (DERRIDA, 1995a, p. 29. A escritura não é, pois, pintura da voz ou transcrição desta. Ela se coloca em relação ao sentido na forma de gravura, sulco, relevo: "uma superfície que pretendemos que seja transmissível ao infinito" (DERRIDA, 1995a, p. 26). Diferenças, para Derrida, são 
efeitos de transformação incompatíveis com os motivos estáticos, sincrônicos, taxonômicos, ahistóricos no conceito de estrutura. A relação entre a escritura e o movimento da différance se dá na superação do conceito tradicional de tempo e no deslocamento do privilégio do presente na história metafísica. Eis aí o primado de uma nova historicidade: o interrogar incessante das categorias.

Nossa reflexão se justifica na medida em que pretendemos expor uma análise preparatória do papel da escritura literária após o desgaste das categorias que procuraram defini-la. Se fundamentalmente trouxemos à discussão as estratégias de deslocamento e desconstrução na estrutura de uma obra, compondo nosso entendimento do jogo de cena representado pela carta de Nhorinhá, no Gsv, no rastro do pensamento derridiano acerca da différance pudemos verificar a questão do literário fora das marcas historicistas, sociologizantes ou antropologizantes. Essa "estranha instituição chamada literatura", de que nos fala Derrida, desafia parâmetros estabelecidos, mas, no desvio de suas próprias proposições, foram esses parâmetros que vieram e vêm lapidando o que chamamos paradoxalmente de especificidade do literário. É a partir daí que procuramos desatar certos nós no entendimento do que o literário é, e a leitura de Guimarães Rosa nos auxilia sobremaneira.

O que para Derrida se insinua como singularidade da escritura não é a própria singularidade absoluta, já que ela, caso existisse, impossibilitaria a leitura. E por quê? Cada texto deve ter como marca certa legibilidade. Legibilidade significa carregar uma série de traços, dividir, participar, pertencer, seja a um gênero, um contexto, um sentido etc. $\mathrm{O}$ que o fenômeno da singularidade diferida no/do texto literário carrega como marca distintiva confunde-se, na lei- tura crítica, com princípios fundamentais da atividade filosófica. E, de fato, como já vimos anteriormente, o saber acerca da literatura atrelou-se, especialmente a partir de Platão, ao conhecimento filosófico. Se a escritura, em geral, já se apresentava como dual sem ser dicotômica (restauradora da memória, ao mesmo tempo em que produz uma perda e esvaziamento da experiência, só possível na voz), a escritura literária representava um duplo distanciamento do ideal elaborado por Platão. Daí que, ao considerar o texto literário como radicalmente situado, sem poder ser reduzido pela crítica ou pela contemplação teórica, Derrida mostraria que a singularidade da escritura literária se estabeleceu no fato de que, ao ser escrito e lido em uma época particular, em um lugar particular, a cada vez e de uma só vez: o texto desafia a instituição da presença que o quer ver sob o crivo das categorias estabelecidas e condicionado historicamente - e esse movimento produz uma visão filosófica do texto a qual reforça a verdade da filosofia, mas diz pouco sobre a verdade do literário.

A questão que surge ao discutirmos o papel do pensamento crítico em sua relação com o texto (precisamente, em Grande sertão: veredas) é saber de que forma ele pode refletir a verdade do literário. Ainda: o que se firmou na crítica ocidental como definição do literário? Mais do que isso, o que pensa o literário é um saber estranho ao literário? Pode o texto literário, da mesma forma que a crítica contemporânea pretende, desconstruir a crítica que procura pensá-lo? 0 texto "deslizante" da literatura, discurso singular, como diz Derrida, poderá algum dia se oferecer? Qual o caráter dessa oferenda? 0 que é o oferecer-se de um texto? Essas questões evocam, primeiramente, a problemática do que seja o ato de narrar: quem narra, para quem narra, o que narra, de que forma nar- 
ra? Inclinados antes a ver no autor o ponto de partida para a compreensão do texto literário, já não sabemos que é em ausência que a escritura se lança no devir? Ou se, por outro lado, concentramos no destinatário a chave da compreensão do texto, também não sabemos de antemão que ele (o destinatário) é apenas promessa, horizonte de expectativas cujas "respostas" são determinadas por seu contexto histórico (do leitor), por sua compreensão da obra como tributária deste contexto? Além disso, a interpretação do leitor será sempre marcada por aquilo que o afeta e produz sua compreensão do mundo (diversa em forma e conteúdo da experiência do outro, também singular), única no modo de abordar e entender o texto. Mais do que buscar um ponto de apoio para a análise do texto literário, é preciso compreender como o próprio texto "escorrega" sobre estas verdades e as desmascara como construção hegemônica da verdade - centrada, redutora. Neste sentido, todo texto é desconstrutor, confirmando o temor platônico de que a escritura - sem pai, sem centro, sem presença, sem destinatário certo - viesse a instituir um saber fora do logos e da razão, perturbando as ideias de Bem, de Bom e de Belo, que se chocam com o ideal de um saber desregulador calcado na produção incessante de questões.

Na prosa do Gsv, a fala de Riobaldo torna a questão da presença o modo-de-ser de um discurso. Entretanto, esta fala só pode ser "lida", só pode ser compreendida através do texto, que se encarrega de endereçá-la a outrem. 0 texto elimina a presença-a-si daquele que se diz "dono da voz" - voz que só permanece como eco do que poderia ter sido, já que o texto se inscreve como apagamento da presença-a-si - e passa a viver dessa liberdade propiciada pela orfandade. Sem centro, desregulador, o texto passa a valer no diálogo com o leitor-receptor que se doa no/ao texto ao estabelecer na interpretação vontades e verdades singulares. Essa "loucura do centro", esse processo disseminatório, torna o texto uma presença-asi que se apaga ou rasura a cada vez que ele é colocado em cena pela leitura.

Portanto, refletir sobre essas questões textuais e filosóficas nos fará sempre e necessariamente pensar a literatura e seu papel na desconstrução da metafísica ocidental. Michel Foucault (1990, p. 59) argumentava que a literatura "manifesta o reaparecimento, onde era inesperado, do ser vivo da linguagem", e é na qualidade de linguagem privilegiada de um saber descentrado que trataremos do fenômeno da escritura na prosa do Gsv. Pensar o questionamento de Riobaldo em torno da construção de mundo que o conduziu ao impasse e ao engano - Riobaldo não arrisca, permanece na iminência do risco, sob o risco, mas não ainda como ser-riscado por uma verdade aparente/inaparente que ele não tem a coragem de desvelar - é procurar entender um certo caminhar do ocidente, que precisa ultrapassar a rigidez militar do logos para abrir-se ao pensamento mais generoso acerca dos indecidíveis que nos rodeiam.

Por tudo o que examinamos, cabe ainda frisar que nossa escolha - difícil, laboriosa, perigosa - do pensamento derridiano para a análise de um traço do texto ficcional proposto - Grande sertão: veredas - requer uma revisão, ou melhor, uma releitura constante da tradição do pensamento que interroga o literário e que ainda se encontra, ora arraigada a um persistente percurso metafísico, ora ligada a um viés sociológico, do qual não negamos o valor, mas que por vezes acaba por reduzir a complexidade do fenômeno literário a causas, por vezes, estranhas ao texto literário. Dessa forma, tocar nas questões cruciais da literatura, hoje, significa ressal- 
tar contribuições da teoria, como a que traz ao debate o pensamento da différance e o conceito derridiano de "texto".

Esta reflexão se concentrou, portanto, em uma tentativa de leitura não canônica do Grande sertão: veredas, visando a compreender de que forma esta obra contribui para o pensamento de uma corrente de pensamento radical e desconstrutora das noções acabadas e das fantasias de verdade. Diremos, enfim, que o projeto roseano está comprometido com o rompimento de uma tradição crítica ainda atada ao platonismo. Cientes do risco, pudemos, no entanto, tratar de uma poética da escritura, de uma metáfora escritural, do traço, do destino da carta sem destinatário certo em uma poética cujo projeto demanda a desconstrução dos diversos postulados que até hoje advogam o direito de posse sobre o texto, mas que, no entanto, desconhecem, por exemplo, a bela definição de literatura que nos deu Derrida (1995c, p. 47) e com a qual fecharemos nossa exposição introdutória:

A literatura é uma invenção moderna, inscreve-se em convenções e instituições que, retendo apenas esse traço, asseguram-lhe em princípio "o direito de dizer tudo". A literatura liga, assim, seu destino a uma determinada não-censura, ao espaço da liberdade democrática (liberdade de imprensa, de opinião etc.). Não há democracia sem literatura, não há literatura sem democracia. Sempre é possível não querer saber nem de uma nem de outra, mas ninguém deixa de passar sem elas sob qualquer regime; é possível não as considerar, nem uma nem a outra, como bens incondicionáveis e direitos indispensáveis. Mas não é possível, em caso algum, dissociá-las uma da outra. Nenhuma seria capaz disso. Cada vez que uma obra literária é censurada, a democracia corre perigo, e todo mundo está de acordo quanto a isso. A possibilidade da literatura, a autorização que uma sociedade lhe dá, o fato de levantar suspeitas ou terror a seu respeito, tudo isso vai junto - politicamente - com o direito ilimitado de fazer todas as perguntas, de suspeitar de todos os dogmatismos, de analisar todas as pressuposições, quer as da ética, quer as da política de responsabilidade.

Pensemos, pois, e deixemos ao abrigo da reflexão essa possibilidade de se dizer e pensar tudo, especialmente em tempos tão duros, em que, mais do que nunca, precisamos lutar por um retorno triunfal das $\mathrm{Hu}-$ manidades.

\section{Referências}

DERRIDA, Jacques. Dissemination. Chicago: The Chicago University Press, 1981.

Limited inc. Trad. Constança Marcondes Cesar. Campinas, SP: Papirus, 1991a.

. A farmácia de Platão. Trad. Rogério da Costa. Trad. São Paulo: Iluminuras, 1991b.

Margens da filosofia. Trad. Joaquim Torres Costa; Antônio M. Magalhães. Revisão técnica Constança Marcondes Cesar. Campinas, SP: Papirus, 1991c.

A escritura e a diferença. Trad. Maria Beatriz Marques Nizza da Silva. 2. ed. São Paulo: Perspectiva, 1995a.

The ear of the other: otobiography, transference, translation. Lincoln and London: University of Nebraska Press, 1995b.

. Paixões. Trad. Lóris Z. Machado. Campinas, SP: Papirus, 1995c.

FOUCAULT, Michel. Trad. Salma Tannus Muchail. As palavras e as coisas: uma arqueologia das ciências humanas. Trad. 5. ed. São Paulo: Martins Fontes, 1990.

ROSA, João Guimarães. Grande sertão: veredas. 23. ed. Rio de Janeiro, Nova Fronteira, 1986.

SANTIAGO, Silviano (Org). Glossário de Derrida. Rio de Janeiro: Francisco Alves, 1976.

Recebido em: $15 / 10 / 2020$ Aprovado em: 30/10/2020 